\title{
Enhancing the cement quality using polypropylene fiber
}

\author{
Salaheldin Elkatatny ${ }^{1}\left[\right.$ Rahul Gajbhiye $^{1} \cdot$ Anas Ahmed $^{1} \cdot$ Ahmed Abdulhamid Mahmoud $^{1}$
}

Received: 24 January 2019 / Accepted: 10 November 2019 / Published online: 27 November 2019

(c) The Author(s) 2019

\begin{abstract}
Durability and long-term integrity of oil well cement are the most important parameters to be considered while designing the cement slurry, especially in the high-pressure and high-temperature (HPHT) environments. In this study, the effect of adding the polypropylene fiber (PPF) to Saudi Class G cement is evaluated under HPHT conditions. The effect of the PPF on the cement compressive and tensile strength, thickening time, density, free water, porosity, and permeability was studied. The effect of the PPF particles on the cement sheath microstructure was studied through powder X-ray diffraction (XRD) and scanning electron microscope. The results obtained showed that PPF did not affect the cement rheology, density, and free water. The addition of PPF considerably decreased the thickening time and improved the tensile and compressive strength of the cement. $0.75 \%$ by weight of cement (BWOC) of PPF reduced the thickening time by $75 \%$, from 317 to $78 \mathrm{~min}$. The compressive strength of the cement increased by $17.8 \%$ after adding $0.5 \%$ BWOC of PPF, while the tensile strength increased by $18 \%$ when $0.75 \%$ of PPF is used which is attributed to the formation of stable forms of calcium silicate hydrates because of the ability of PPF to accelerate cement hydration process as indicated by the XRD results. The ability of the PPF to decrease the cement thickening time along with its ability to improve the cement strength suggests the use of PPF as an alternative for silica floor in shallow wells where a reduction in thickening time will decrease the wait on cement time. Porosity and permeability of the base cement were also decreased by incorporating PPF because of the pores filling effect of PPF particles as indicated by the microstructure analysis.
\end{abstract}

Keywords Cement $\cdot$ Fiber $\cdot$ Polypropylene fiber $\cdot$ Quality $\cdot$ High-temperature $\cdot$ Compressive strength

$\begin{array}{ll}\text { Abbreviations } \\ \text { API } & \text { American Petroleum Institute } \\ \text { ASTM } & \text { American Society for Testing and Materials } \\ \text { Bc } & \text { Bearden units of consistency } \\ \text { BWOC } & \text { By weight of cement } \\ \text { HPHT } & \text { High pressure and high temperature } \\ \text { OWC } & \text { Oil well cement } \\ \text { PPF } & \text { Polypropylene fiber }\end{array}$

Rahul Gajbhiye

rahulg@kfupm.edu.sa

Salaheldin Elkatatny

elkatatny@kfupm.edu.sa

Anas Ahmed

anaspetrol@hotmail.com

Ahmed Abdulhamid Mahmoud

eng.ahmedmahmoud06@gmail.com

1 Department of Petroleum Engineering, College of Petroleum Engineering and Geosciences, King Fahd University of Petroleum and Minerals, Dhahran 31261, Saudi Arabia

$\begin{array}{ll}\text { ppg } & \text { Pounds per gallon } \\ \mathrm{mD} & \text { Milli-Darcy }\end{array}$

\section{Introduction}

After the oil or gas well is drilled, it must be cased and cemented to withstand the formation pressure. The cemented casing in the borehole could add more stability to the wellbore and allows post cementing operations to be performed safely, it could also achieve zonal isolation and prevent fluids communication behind the casing (Parcevaux and Sault 1984; Bourgoyne et al. 1986; Shahriar 2011).

The producing well performance depends largely on the quality of the primary cementing job. Poor quality of cement slurry and solidified cement matrix behind the casing may lead to the need for remedial cementing which will significantly increase the operational cost of the well. Proper laboratory job simulation is needed to select the best composition of the cement slurries to ensure a successful cement job (Calvert and Smith 1990). 
Portland cement experiences many structural changes when subjected to high-temperature conditions (i.e., higher than $230^{\circ} \mathrm{F}$ ), such a phenomenon is known as strength retrogression (Taylor 1997; Luke 2004; Nelson and Guillot 2006). These changes influence the cement matrix compressive strength, promote the evolutions of micro-cracks caused by cement shrinkage under the thermal stresses; therefore, it could increase the cement matrix permeability, and hence, drastically decrease its durability and strength (Shahriar 2011; Ugwu 2008).

Al-Buraik et al. (1998) discussed the challenges associated with a shallow gas zone located at $400-1000 \mathrm{ft}$ below the surface. After setting the casing and cementation, the gas migrated to the surface indicating that the cement did not hold in place. To overcome this issue, it was decided to design a cement to set quickly once it is pumped. This was done by using lightweight latex slurry, and quick-setting cement was designed which reduced fluid loss and shorten thickening time. The limitation was the low compressive strength and the chance of flash setting while pumping. To achieve successful and safe cementing operations, the cement slurry should be designed to withstand the gas flux during and after quick placement in the formation Rogers et al. (2004).

There were several studies conducted on cement to improve its properties and to make it usable at different reservoir conditions in a cost-effective manner. Recently, several new materials were introduced to improve the properties of both the cement slurry and solidified cement sheath such as nanoclay, foam, ash, microsphere, beads, and fibers.

Several previous studies suggested the use of different types of fibers such as the Wollastonite, organic, monofilament, and silicic fibers to improve properties of oil well cement at different conditions, the evaluated fibers were able to improve the strength (Shi et al. 1995; Heinold et al. 2002; Morris et al. 2003; Iremonger et al. 2015) and mitigate the loss circulation (Elmoneim et al. 2000; Ilyas et al. 2012; Al Maskary et al. 2014; Arshad et al. 2014) of the cement.

The synthetic polypropylene fiber (PPF) has been used for soil reinforcement at lab scale where it confirmed high ability to improve the compressive and tensile strengths of the soil (Santoni et al. 2001; Yetimoglu and Salbas 2003; Yetimoglu et al. 2005; Khattak and Alrashidi 2006; Tang et al. 2007; Viswanadham et al. 2009). PPF is also able to reduce the soil shrinkage properties and enabled to mitigate the soil biological and chemical degradation (Musenda 1999; Puppala and Musenda 2000; Vasudev 2007).

The previous studies confirm that fibers could improve the wellbore integrity by enhancing the cement mechanical properties and reducing the loss circulation. Recently, with the need to drill very deep wells as well as the necessity to use thermal techniques to improve oil recovery, the need to have a cement that can withstand into these high-temperature and high-pressure (HPHT) environments increased drastically (Mahmoud et al. 2018; Mahmoud and Elkatatny 2019a; Mahmoud et al. 2019); therefore, there were continuous efforts to investigate the newly developed fibers which can sustain the HPHT condition and improve the cement performance.

This study aims to evaluate the applicability of using the PPF as a complementary additive to improve the properties of the slurry and solidified Saudi Class G oil well cement under the high-pressure and high-temperature (HPHT) conditions usually encountered in oil or gas well.

\section{Experimental procedures}

In this study, the cement slurries were prepared and tested according to the American Petroleum Institute standard procedure (API 2013). The materials used in this study, the cement slurry preparation procedures, and the evaluated properties of the cement slurry and cement matrix are discussed in the following sections.

\section{Cement slurry preparation and additives}

The cement slurries were prepared in this study as a mixture of Saudi Class G cement, silica flour, extender, retarder, friction reducer, fluid loss control agent, anti-foaming agent, PPF, and water. High sulfate resistance Saudi Class $\mathrm{G}$ cement with a specific gravity of 3.14 and the chemical composition as characterized by powder XRD summarized in Table 1 were used in this study. The cement slurries were prepared with silica flour, extender, retarded, friction reducer, fluid loss control agent, and ant anti-foaming additives provided by a service company.

PPF is synthetically prepared polypropylene fiber with the physical properties and specifications summarized in Table 2. PPF particles used in this study have a triangularshaped structure that provides a higher surface area and

Table 1 Chemical composition of Saudi Class G cement

\begin{tabular}{lc}
\hline Phase & wt $\%$ \\
\hline Silica $\left(\mathrm{SiO}_{2}\right)$ & 21.6 \\
Alumina $\left(\mathrm{Al}_{2} \mathrm{O}_{3}\right)$ & 3.6 \\
Iron oxide $\left(\mathrm{Fe}_{2} \mathrm{O}_{3}\right)$ & 4.9 \\
Calcium oxide, total $(\mathrm{TCaO})$ & 64.22 \\
Magnesium oxide $(\mathrm{MgO})$ & 1.6 \\
Sulfur trioxide $\left(\mathrm{SO}_{3}\right)$ & 2.5 \\
Loss on ignition & 0.6 \\
Insoluble residue & 0.5 \\
Equivalent alkali $\left(\right.$ as $\left.\mathrm{Na}_{2} \mathrm{O}\right)$ & 0.48 \\
\hline
\end{tabular}


Table 2 Commercialized PPF specifications (Madhavi et al. 2015; Patel et al. 2015)

\begin{tabular}{ll}
\hline Property & Value \\
\hline Cut length & 6-12 mm (high surface area) \\
$\begin{array}{l}\text { Fiber shape (triangular } \\
\text { cross section) }\end{array}$ & $\begin{array}{c}\text { Special for aggregated cement holding } \\
\text { improvement }\end{array}$ \\
Tensile strength & $4000-6000 \mathrm{~kg} / \mathrm{cm}^{2}(56,000-85,000 \mathrm{psi})$ \\
Melting point & Greater than $250{ }^{\circ} \mathrm{C}\left(482{ }^{\circ} \mathrm{F}\right)$ \\
\hline
\end{tabular}

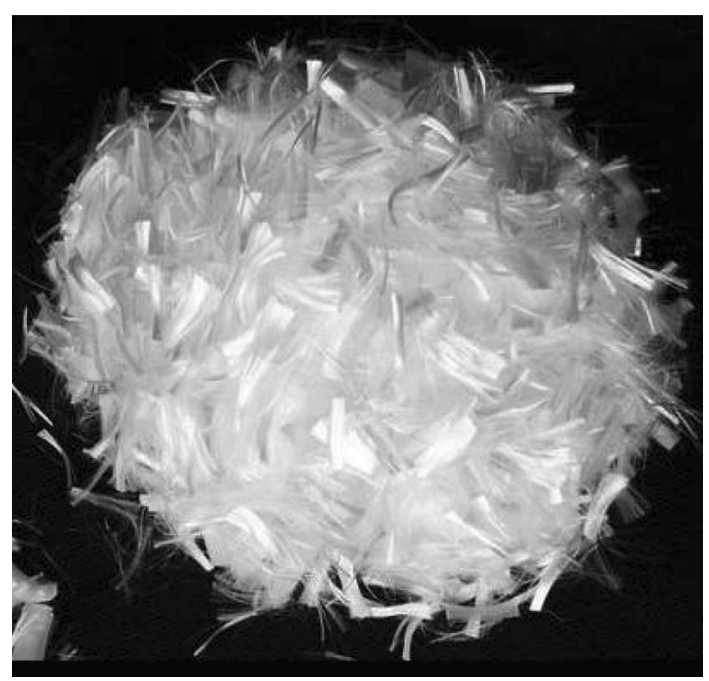

Fig. 1 PPF structure

higher flexural strength than the ordinary rounded shape fibers as shown in Fig. 1 (Park et al. 2003; Liu et al. 2012).

Figure 2 illustrates the main mechanism of the fiber for creating a mesh network which could improve the strength of the cement as well as further control of circulation losses. PPF could also effectively improve the cement resistance to shrinkage cracking, prevent initiation and propagation of the micro-cracks, improve cement matrix flexural strength, reduce the surface water absorption and the cement permeability, and improve the durability of cement.
The previous discussion indicates that PPF may improve the oil-well cement quality and could be considered as a complementary additive for oil well cement. Unlike concrete, oil-well cement preparation, placement, and subsurface environment are completely different. Also, the results of the concrete are not directly applicable to the oil well cement; hence, it is important to examine the use of PPF for enhancing oil-well cement quality.

Table 3 summarizes the concentration of the additives used to prepare the base cement slurry which has $0 \%$ BWOC of PPF, to prepare the PPF-based cement slurries $0.25,0.5$, $0.75 \%$ BWOC of the PPF were added to the base cement. The cement properties were also tested for a slurry prepared using only Saudi Class G cement and fiber without any other additive to evaluate the effect of including PPF alone.

\section{Evaluated properties}

The prepared cement slurries have been tested for the density, thickening time, free water separation and rheological properties, the cement matrix properties of the microstructure, compressive and tensile strengths, porosity, and permeability were also evaluated. Samples preparation and the conditions of every test will be discussed in the next sections; all properties were evaluated according to the API standards (API 2013, 2019).

\section{Cement density}

The pressurized fluid density balance was used to measure the cement slurries density. After conditioning the cement slurries at $194^{\circ} \mathrm{F}$, it was directly poured into the measuring cell, the cell was then pressurized until all the trapped air is removed, after that the cement density is measured.

\section{Rheological properties}

A high-temperature (HT) variable speed rheometer was used to measure the cement slurry rheological properties of the yield point, plastic viscosity, and gel strength.
Fig. 2 Fiber mechanism on creating the mesh network to control the loss circulation (Messier et al. 2003)

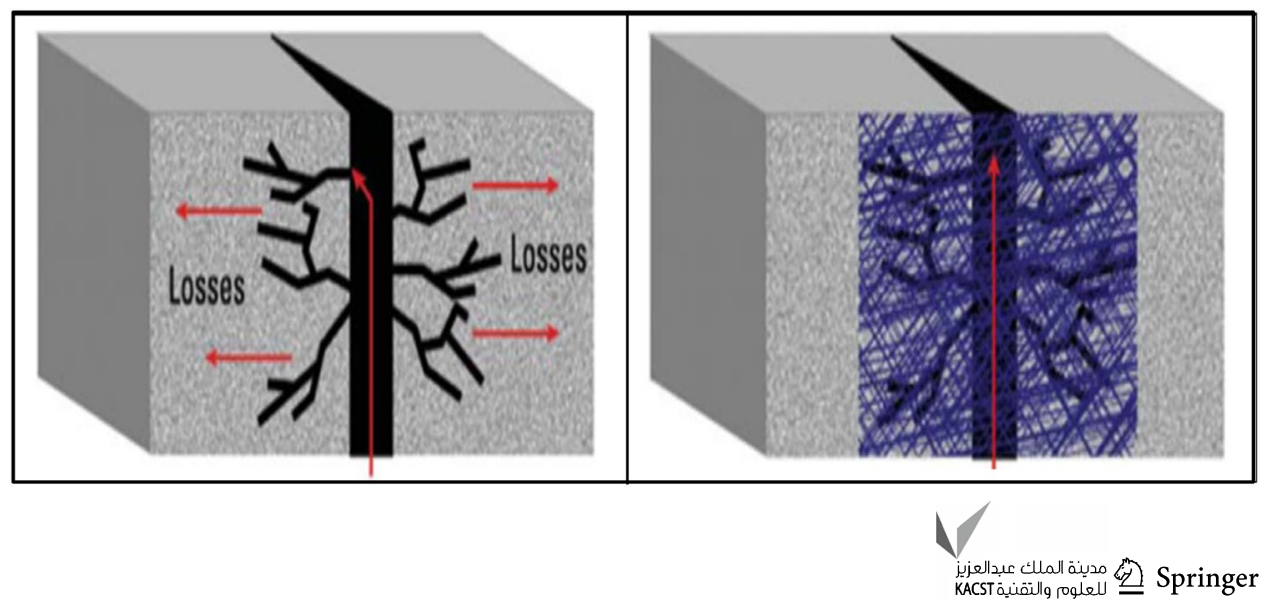


Table 3 Composition of the base cement slurry used in this study

\begin{tabular}{ll}
\hline Additives & $\begin{array}{l}\text { Concen- } \\
\text { tration } \\
(\% \text { BWOC) }\end{array}$ \\
\hline Silica flour & 35 \\
Extender & 1 \\
Retarder & 1.5 \\
Friction reducer & 0.4 \\
Fluid loss controlling agent & 0.7 \\
Anti-foaming agent & 0.01 \\
Water & 44 \\
\hline
\end{tabular}

\section{Thickening time}

The HPHT consistometer was used to evaluate the slurry thickening time. The time needed for all the cement slurries with the concentrations of $0 \%, 0.25 \%, 0.5 \%$, and $0.75 \%$ BWOC of PPF to reach 100 Bearden units of consistency (Bc) at $9300 \mathrm{psi}$ and $228^{\circ} \mathrm{F}$ was recorded as the slurry thickening time.

\section{Free water separation}

Free water was measured using a graduated cylinder after slurry conditioning for $20 \mathrm{~min}$ at $194^{\circ} \mathrm{F}$. The cement slurry was poured into the graduated cylinder, the top of the cylinder was covered with aluminum foil, then the slurry was kept for $2 \mathrm{~h}$, after that the water volume present on the top of cement which represents the free water content for the specific slurry was measured.

\section{Microstructural analysis}

XRD and SEM techniques were used to study the changes in the microstructure of the solidified cement matrix caused by the addition of the PPF. The changes in the cement hydration products were studied by the powder XRD, while the changes in the cement sheath pore structure and topography were investigated by the scanning electron microscope (SEM) technique. All samples studied in this section were cured for $24 \mathrm{~h}$ at $292^{\circ} \mathrm{F}$ and $3000 \mathrm{psi}$, after that were removed and the samples studied by XRD were grinded to form a powder.

The main hydration products of the pure Portland cement mixed with water are the portlandite $\left(\mathrm{Ca}(\mathrm{OH})_{2}\right.$ or $\mathrm{CH})$, different calcium silicate hydrates $(\mathrm{C}-\mathrm{S}-\mathrm{H})$ such as $\mathrm{CSH}\left(\mathrm{CaSiO}_{4.3} \mathrm{H}_{2} \mathrm{O}\right), \mathrm{C}_{2} \mathrm{SH}_{2}\left(\mathrm{CaSiO}_{4.2} \mathrm{H}_{2} \mathrm{O}\right)$, and $\mathrm{C}_{3} \mathrm{~S}_{2} \mathrm{H}_{3}$ $\left(\mathrm{Ca}_{3}\left(\mathrm{HSiO}_{4}\right)_{2.2} \mathrm{H}_{2} \mathrm{O}\right)$ (Brouwers 2004; Bahafid et al. 2017), ettringite $\left(3 \mathrm{CaO} \cdot \mathrm{Al}_{2} \mathrm{O}_{3} \cdot \mathrm{CaSO}_{4} \cdot 32 \mathrm{H}_{2} \mathrm{O}\right)$ (Abid et al. 2015), and unhydrated products of $\mathrm{C}_{2} \mathrm{~S}$ and $\mathrm{C}_{3} \mathrm{~S}$ may exist with a very low concentration (Duguid et al. 2011). When silica flour is mixed with the cement, the hydration products and their concentrations will considerably change especially under the HPHT conditions of $292^{\circ} \mathrm{F}$ and 3000 psi considered in this study. The addition of silica flour to the cement usually leads to disappearance of the $\mathrm{CH}$ peaks while the specific peak of $\mathrm{SiO}_{2}$ usually appears compared to the products of the neat cement hydration as shown in Fig. 3a for the base cement with $35 \%$ of silica; Fig. 3a also indicates that the peaks of the $\mathrm{CH}$ and $\mathrm{C}_{2} \mathrm{SH}$ were almost disappeared while the $\mathrm{C}-\mathrm{S}-\mathrm{H}$ appeared in the form of $\mathrm{C}_{5} \mathrm{~S}_{6} \mathrm{H}_{5}$ (tobermorite) and peaks of $\mathrm{SiO}_{2}$ still appear in the XRD pattern. $\mathrm{C}_{5} \mathrm{~S}_{6} \mathrm{H}_{5}$ is more stable at high-temperature conditions than $\mathrm{CH}$, the needle shape of the $\mathrm{C}_{5} \mathrm{~S}_{6} \mathrm{H}_{5}$ enables its particles to combine, and hence, it will form an ideal network structure for the solidified cement sheath as indicated by the SEM image in Fig. 4a.

The addition of the PPF particles leads to disappearance of the $\mathrm{CH}$ peaks after $24 \mathrm{~h}$ of cement hydration as shown in Fig. 3b-d. This indicates that the PPF can accelerate the cement hydration process, as indicated in Fig. $3 b-d$ that the quartz and $\mathrm{C}-\mathrm{S}-\mathrm{H}$ peaks are increasing with the PPF concentration and they are all greater than the $\mathrm{C}-\mathrm{S}-\mathrm{H}$ peaks for the base cement shown in Fig. 3a. The increase in C-S-H concentration combined with the disappearance of the $\mathrm{CH}$ is expected to enhance the cement strength due to the ability of the $\mathrm{C}-\mathrm{S}-\mathrm{H}$ particles to interweave and bond with each other to form a perfect network structure after the cement is solidified as shown in Fig. 4b-d and reported earlier by Mahmoud and Elkatatny (2019b).

\section{Compressive strength}

The conditioned cement slurry was used to prepare cubical samples with 2 in. edge using cubical molds. The molds were placed in the HPHT curing vessel at $292{ }^{\circ} \mathrm{F}$ and 3000 psi for $24 \mathrm{~h}$. The cured cubes were then used to measure the cement compressive strength through the crushing technique and following the American Society for Testing and Materials standard ASTM C109/C109M (ASTM 2016) and (API 2019). Three samples which represent every specimen were used for compressive strength measurement, and the average compressive strength of the three samples was considered as the specimen compressive strength.

\section{Brazilian tensile strength}

To determine the tensile strength, the prepared slurries were poured into cubical metallic molds with 2 in. edge and then cured at $292^{\circ} \mathrm{F}$ and $3000 \mathrm{psi}$ for $24 \mathrm{~h}$ using the HPHT curing chamber, core plugs of $1 \mathrm{in}$. in diameter and $0.5 \mathrm{in}$. in length were cored out of the cubical samples, the core plugs were then loaded diametrically which caused a tensile deformation perpendicular to the loading direction, and this yielded a 
Fig. 3 XRD patterns for the hydrated a base cement, $\mathbf{b}$ $0.25 \%$ PPF cement, c $0.50 \%$ PPF cement, and $\mathbf{d} 0.75 \%$ PPF samples, after $24 \mathrm{~h}$ of curing at $292^{\circ} \mathrm{F}$ and $3000 \mathrm{psi}$
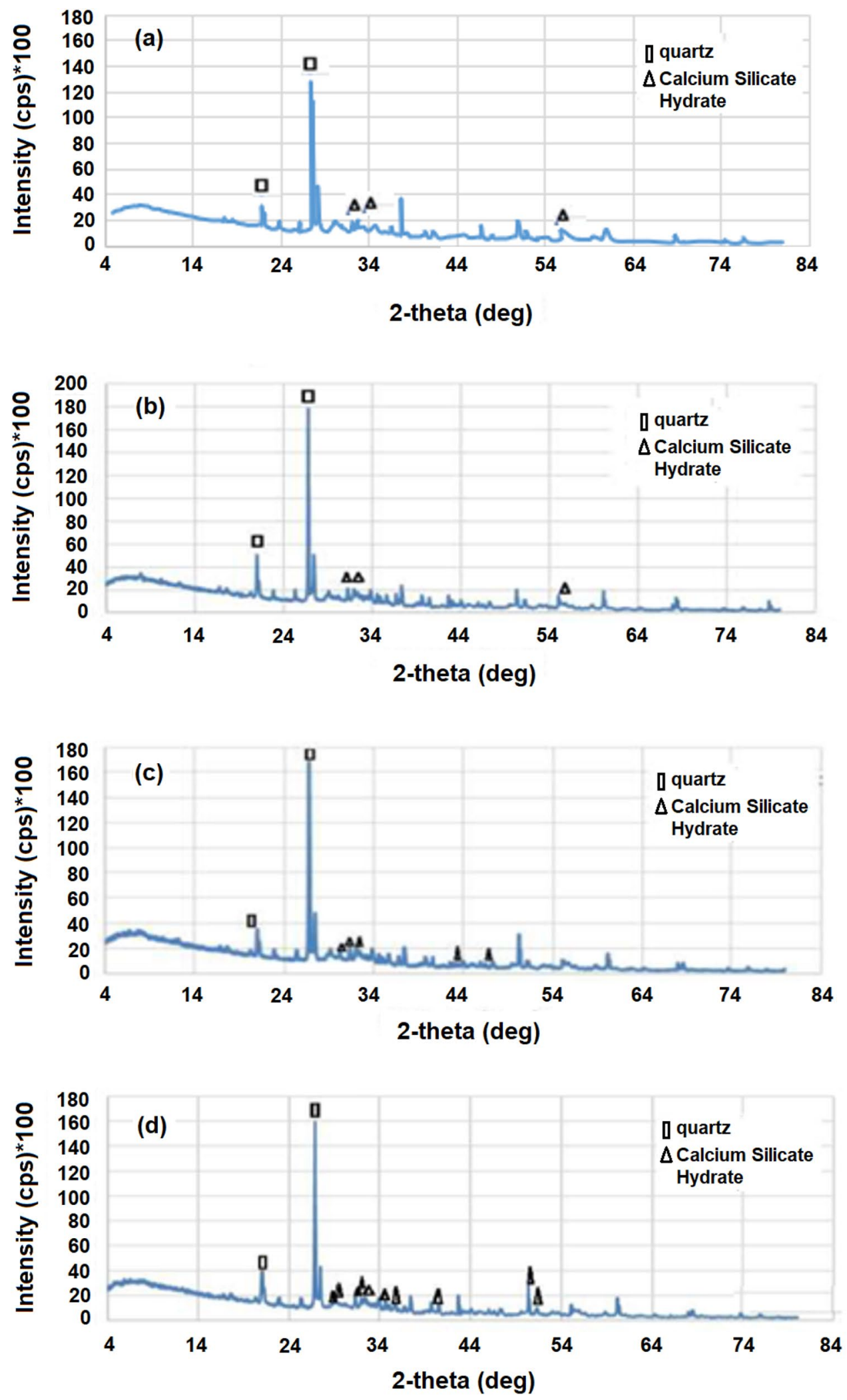

tensile failure as shown in Fig. 5. The ultimate load the core sample could withstand before failure was recorded; then, the load and the sample dimensions were used to calculate the Brazilian tensile strength of the cement samples. The reported tensile strength in this study is the average strength of three specimens. 
Fig. 4 SEM images for the hydrated a base cement, $\mathbf{b}$ $0.25 \%$ PPF cement, $\mathbf{c} 0.50 \%$ PPF cement, and $\mathbf{d} 0.75 \%$ PPF cement, after $24 \mathrm{~h}$ of curing at $292{ }^{\circ} \mathrm{F}$ and $3000 \mathrm{psi}$
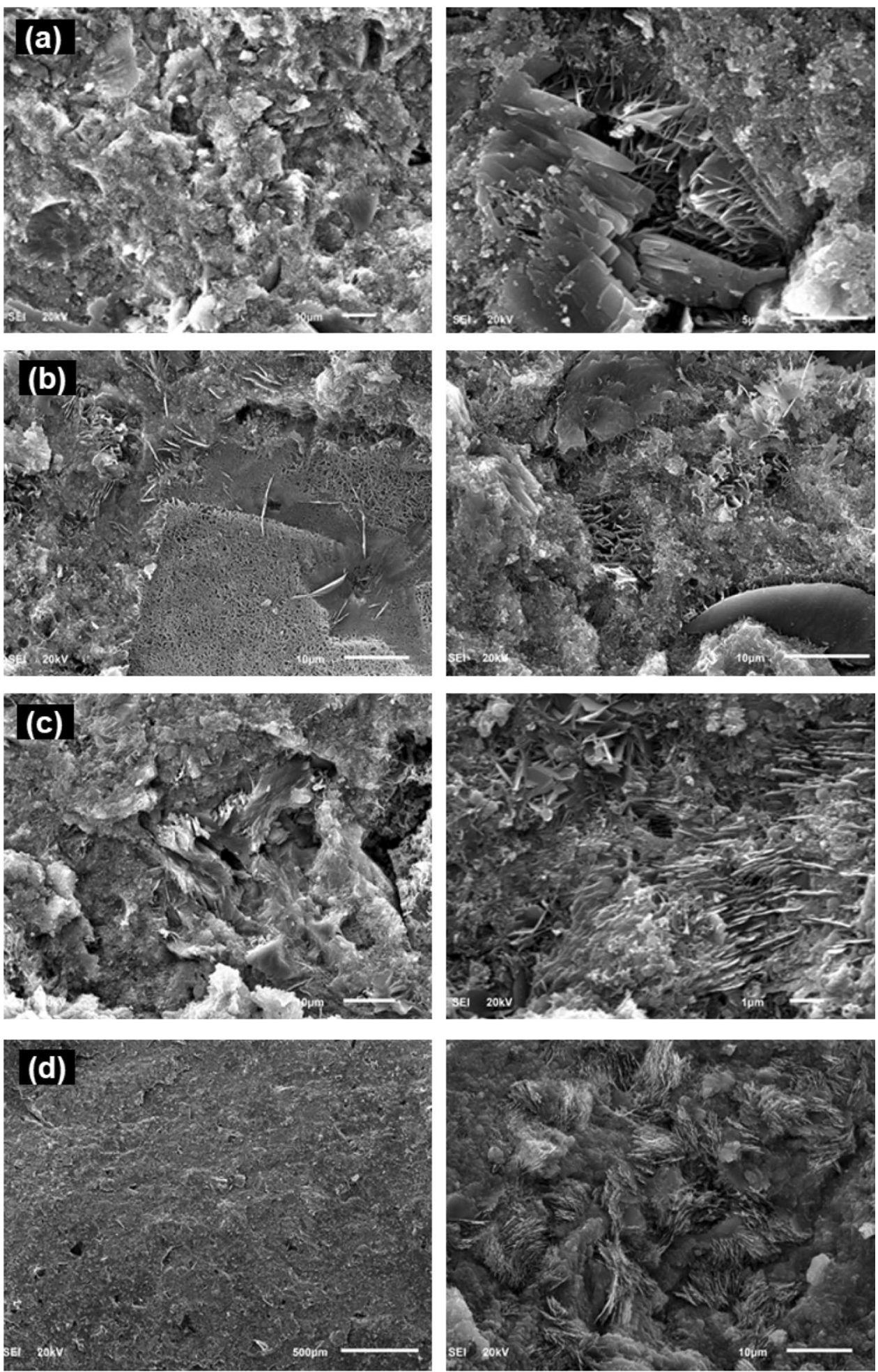

\section{Porosity and permeability}

Cement cubes with 2 in. edge are prepared following the same procedure used to prepare the samples used for compressive strength testing; then, cement plugs with $1 \mathrm{in}$. in diameter and $1 \mathrm{in}$. in length were drilled from the cured cubes. The automated Porosimeter-Permeameter (AP608) was used to measure the porosity and gas permeability of the cement plugs under a confining pressure of 500 psi. 
Fig. 5 Left: the disk-shaped specimens cut from the cement plugs. Middle: cement cylindrical sample while subjected to load across its circumference for the tensile strength measurement. Right: cement cylinders after the Brazilian tensile strength testing

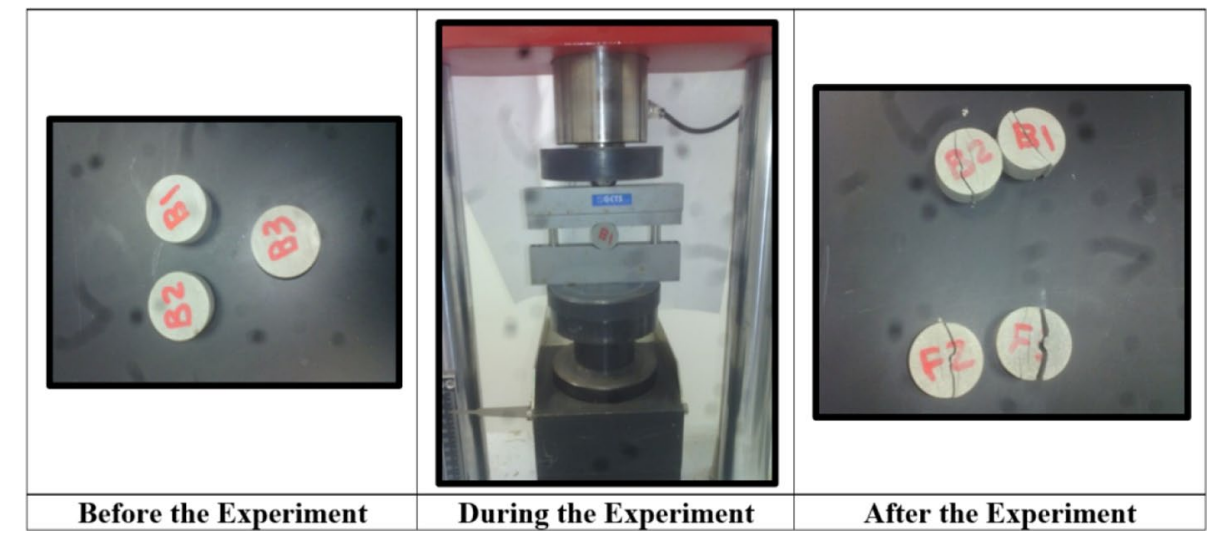

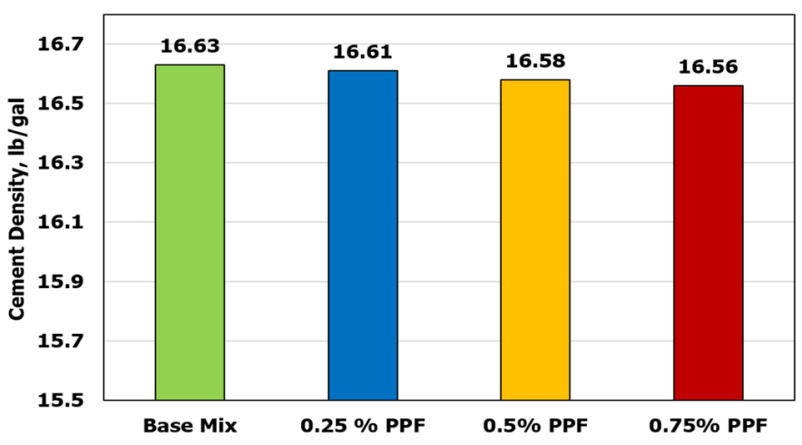

Fig. 6 Effect of adding PPF on the cement density

\section{Results and discussion}

\section{Density and rheological properties}

Figure 6 summarizes the results of the cement slurry density. The base cement slurry has a density of $16.60 \mathrm{lb}$ per gallon (ppg), the addition of the PPF decreased the cement density linearly with a very small rate as shown in Fig. 6. The PPF-based sample with $0.75 \%$ PPF density is $16.56 \mathrm{ppg}$, which is only $0.4 \%$ less than the base sample density. This small decrease in the cement slurry density could help on improving the slurry displacement process; therefore, it enhances zonal isolation before cement solidification.

The base cement has a plastic viscosity and yield point of $263 \mathrm{cP}$ and $6 \mathrm{lb} / 100 \mathrm{ft}^{2}$, respectively, its gel strengths at $10 \mathrm{~s}$ and $10 \mathrm{~min}$ are 6 and $23 \mathrm{lb} / 100 \mathrm{ft}^{2}$, respectively. Table 4 shows that adding the PPF to the base cement slightly changed the plastic viscosity of the base cement, adding 0.75 BWOC PPF to the base cement reduced the plastic viscosity by $0.4 \%$. In general, reduction in viscosity is better for cement pumpability (Elkatatny 2019; Mahmoud et al. 2019). The same effect was noted for the yield point, adding 0.75 BWOC of the PPF to the base cement increased its yield point from 6 to $7 \mathrm{lb} / 100 \mathrm{ft}^{2}$. PPF has a negligible effect on the gel strength of the base cement as shown in Table 4.

Based on these results, it can be concluded that incorporating the PPF to the base cement has a minor effect on the density and rheology of the cement slurry.

\section{Thickening time}

Figure 7 summarizes the thickening time results. The initial consistencies of the cement slurries of $0 \%, 0.25 \%, 0.5 \%$, and $0.75 \%$ BWOC of PPF are 40, 55, 56, and $65 \mathrm{Bc}$, respectively. As shown in Fig. 7, a considerable decrease in the cement slurry thickening time was achieved by incorporating the PPF into the base cement slurry. The thickening time for the base slurry was $5 \mathrm{~h}$ and $17 \mathrm{~min}$, it reduced to $3 \mathrm{~h}$ and 26 min by adding $0.25 \%$ BWOC of PPF, and then only slightly decreased to $3 \mathrm{~h}$ and $10 \mathrm{~min}$ by the $0.5 \%$ PPF-based slurry, the $0.75 \%$ PPF slurry has the lowest thickening time of $1 \mathrm{~h}$ and $18 \mathrm{~min}$ which is $75 \%$ less than the thickening time of the base slurry. This result is attributed to the ability of the PPF particles to accelerate the cement hydration process (Mahmoud and Elkatatny 2019c) which leads to reduce
Table 4 Rheological properties of cement slurries with different percentages of PPF

\begin{tabular}{lcccr}
\hline Property & $0 \%$ PPF & $0.25 \%$ PPF & $0.5 \%$ PPF & $0.75 \%$ PPF \\
\hline Plastic viscosity $(\mathrm{cP})$ & 263 & 261 & 260 & 253 \\
Yield point $\left(\mathrm{lb} / 100 \mathrm{ft}^{2}\right)$ & 6 & 6 & 7 & 7 \\
10-s gel strength $\left(\mathrm{lb} / 100 \mathrm{ft}^{2}\right)$ & 6 & 6 & 5 & 5 \\
10-min gel strength $\left(\mathrm{lb} / 100 \mathrm{ft}^{2}\right)$ & 22 & 23 & 23 & 25 \\
\hline
\end{tabular}




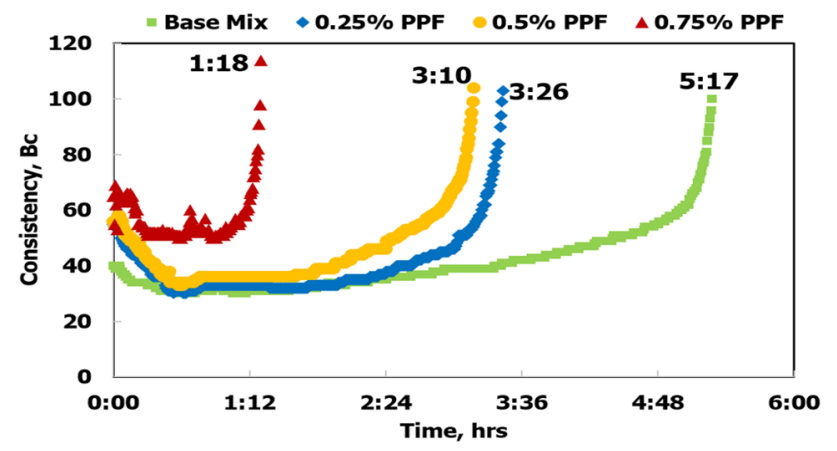

Fig. 7 Thickening time for the cement slurries of $0 \%, 0.25 \%, 0.5 \%$, and $0.75 \% \mathrm{PPF}$

the time needed for the cement to solidify. Accelerating the cement solidification is one of the biggest concerns when it comes to drilling shallow wells. These results give the PPF a great chance to be used in cementing shallow wells.

The time required for the cement slurries to reach consistencies of 40, 70, $100 \mathrm{Bc}$ is compared in Fig. 8. For all cement slurries, the time difference between the consistencies of $40 \mathrm{Bc}$ and $70 \mathrm{Bc}$ is very long compared to the time difference between the consistencies of $70 \mathrm{Bc}$ and $100 \mathrm{Bc}$. So, during the cement design process, the $70 \mathrm{Bc}$ should be considered as an indicator that the cement is becoming unpumpable since the time difference required to reach the $100 \mathrm{Bc}$ after reaching the $70 \mathrm{Bc}$ is considerably short.

\section{Free water separation}

All the cement slurries considered in this work were tested for the free water separation, the results of these tests showed that addition of the PPF to the base slurry resulted in a free water separation of zero which is the same conclusion when base cement is used. Prevention of free water formation is very important to ensure formation homogeneous cement matrix, which is needed to achieve good zonal isolation.

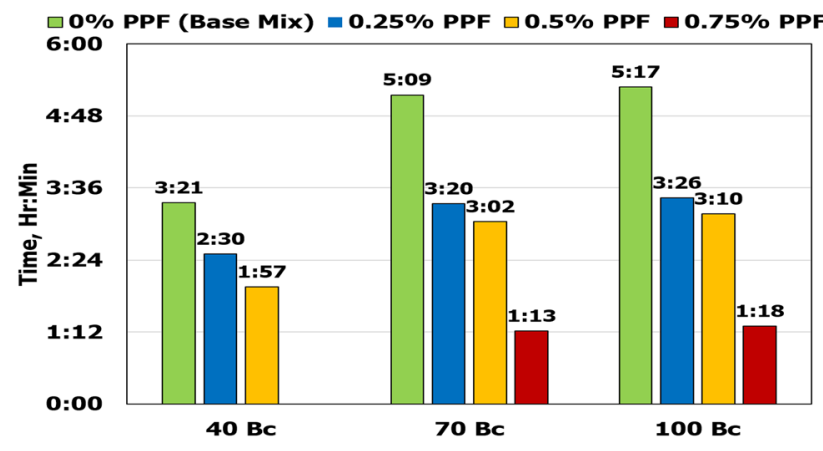

Fig. 8 Time to reach $40 \mathrm{Bc}, 70 \mathrm{Bc}$, and $100 \mathrm{Bc}$ for slurries of $0 \%$, $0.25 \%, 0.5 \%$, and $0.75 \% \mathrm{PPF}$

\section{Compressive strength}

Figure 9 compares the compressive strength results. The base cement compressive strength of 6246 psi was increased to 6726 psi by adding $0.25 \%$ of the PPF to the base cement, this enhancement in the cement compressive strength is attributed to the high silica content of the PPF which enabled acceleration the pozzolanic reaction and formation more $\mathrm{C}-\mathrm{S}-\mathrm{H}$ products as confirmed by the XRD results. Same results were confirmed by Mahmoud and Elkatatny (2019b). The addition of $0.5 \%$ of the PPF increased the base cement strength by $35.03 \%$ to reach 8434 psi as shown in Fig. 9.

To assess the impact of PPF on the compressive strength of the cement, another set of experiments was conducted. Three cement samples with Saudi Class G cement only, Saudi Class G with 35\% BWOC of the silica flour, and Saudi Class G with $0.5 \%$ BWOC of the PPF were prepared. These samples were cured for 1 day at $200{ }^{\circ} \mathrm{C}$ and 3000 psi. The samples were then removed kept in water at room condition for $24 \mathrm{~h}$ and then crushed to find their compressive strength.

Figure 10 shows that adding $35 \%$ silica flour to Saudi Class $\mathrm{G}$ cement increased the cement compressive strength from 4198 psi (for the sample with Saudi Class G cement only) to 4461 psi while adding $0.5 \%$ BWOC of the PPF to Saudi Class G cement increased the compressive strength from 4198 to 4949 psi. These results confirmed the effect of adding PPF on the compressive strength. These results in addition to the thickening time results suggest the use of the PPF as an alternative material for the silica floor in shallow wells. For shallow wells, using $0.5 \%$ BWOC of PPF without the need for any other additives could enhance the compressive strength of the cement and also reduce the thickening time.

\section{Tensile strength}

The four cement systems with PPF of $0 \%, 0.25 \%, 0.5 \%$ and $0.75 \%$ BWOC have been subjected to the tensile strength test. It was observed that the addition of the PPF particles

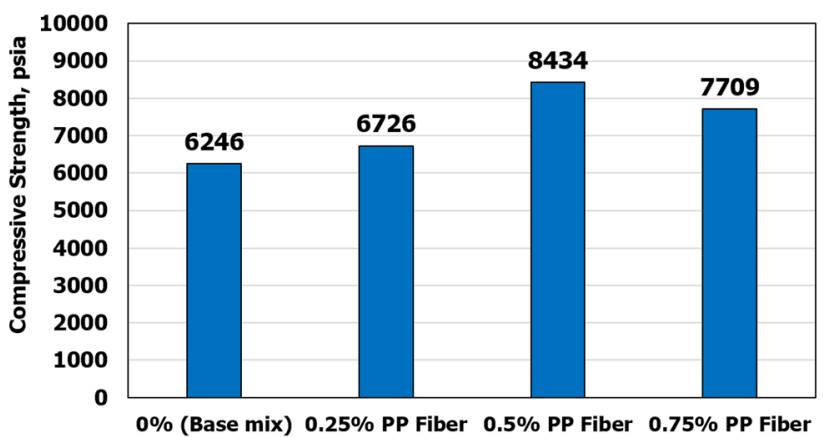

Fig. 9 Cement matrix compressive strength 


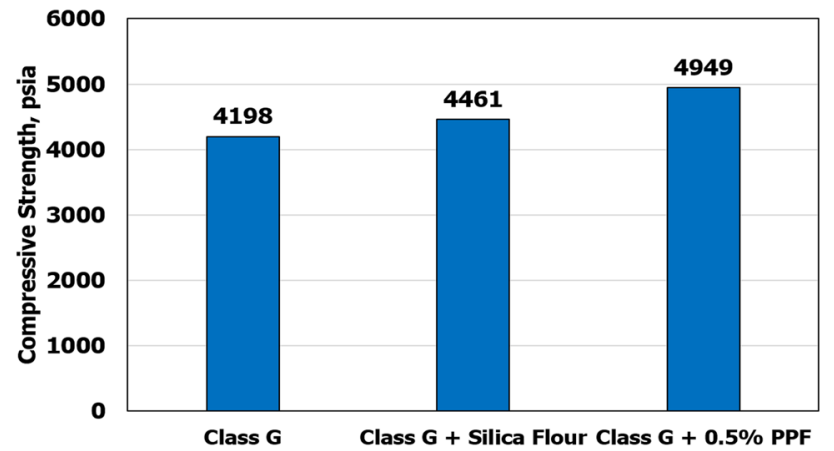

Fig. 10 Effect of adding silica flour and PPF on the compressive strength of Saudi Class G

improved the tensile strength of the base cement (i.e., without PPF). The base cement has a tensile strength of 1333 psi; the tensile strength is increased linearly with the PPF concentration. The $0.75 \%$ BWOC of the PPF improved the tensile strength of the base cement by $18 \%$ (1574 psi) as shown in Fig. 11.

\section{Porosity and permeability}

Table 5 summarizes the porosity and permeability of the cement samples with $0,0.25,0.5$, and $0.75 \%$ BWOC of PPF after $24 \mathrm{~h}$ of curing at $292^{\circ} \mathrm{F}$ and $3000 \mathrm{psi}$. It was observed that both porosity and permeability of the cement decreased by adding the PPF. The porosity of base cement was $27.49 \%$ which was reduced to $25.09 \%$ and $24.56 \%$ by adding $0.25 \%$ and $0.5 \%$ BWOC of PPF, respectively. The addition of $0.75 \%$ BWOC of PPF decreased the porosity of the base cement by $16.8 \%$ to reach $22.86 \%$.

A considerable decrease in the base cement permeability was observed after incorporating the PPF. The base cement permeability of $0.0023 \mathrm{mD}$ was decreased to $0.0010 \mathrm{mD}$ when $0.75 \%$ PPF is added, with a reduction of $56 \%$ compared with the base cement sample.

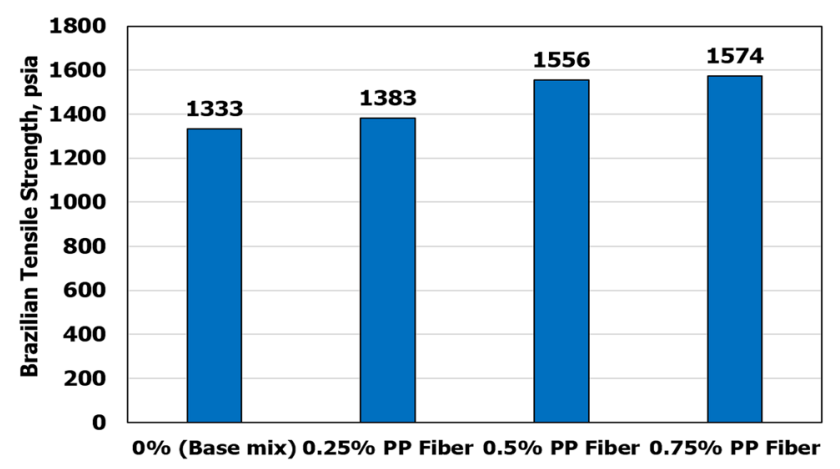

Fig. 11 Brazilian tensile strength for the cement matrices of $0 \%$, $0.25 \%, 0.5 \%$, and $0.75 \% \mathrm{PPF}$
Table 5 Porosity and permeability of cement samples with different percentages of PPF

\begin{tabular}{lcccc}
\hline Property & Base mix & $0.25 \%$ PPF & $0.5 \%$ PPF & $0.75 \%$ PPF \\
\hline Porosity (\%) & 27.49 & 25.09 & 24.56 & 22.86 \\
Permeability (mD) & 0.0023 & 0.002 & 0.0014 & 0.001 \\
\hline
\end{tabular}

The effect of the PPF on the cement porosity and permeability is attributed to the fact that the PPF particles fill the capillary porous, and hence, decreased the pore spaces present in the solidified cement body as confirmed by the SEM results shown earlier in Fig. 4.

\section{Additional cost to prepare one barrel of the new PPF-based cement}

In this section, the additional cost to prepare one barrel of the new PPF-based cement will be discussed. The cost of the PPF is $\$ 2.67 / \mathrm{kg}$, if the slurry with the maximum PPF concentration (i.e., $0.75 \%$ BWOC of PPF) is considered for cost calculations, to prepare one barrel of the slurry with a density of $16.56 \mathrm{ppg}$ (as shown earlier in Fig. 6) and PPF concentration of $0.75 \%$ BWOC; $2.366 \mathrm{~kg}$ of the PPF is needed. So, the additional cost of the cement slurry with $0.75 \%$ BWOC of PPF is $\$ 6.32 /$ barrel of slurry.

\section{Conclusions}

Extensive experimental work was conducted to assess the effect of using polypropylene fiber (PPF) with the base cement under high-pressure and high-temperature (HPHT) conditions. Based on the obtained results, the following conclusions can be drawn:

- The microstructural analysis confirmed the ability of the PPF to effectively fill the capillary pores of the cement, so a dense cement structure is formed.

- Adding PPF to the base cement has a negligible effect on cement density, rheological properties, and free water content.

- The PPF contributed to the increase in the resistance to the axial and perpendicular loads which causes improvement in the cement compressive and tensile strengths. $0.5 \%$ by weight of cement (BWOC) of the PPF increased the compressive strength of Saudi Class G cement by $17.8 \%, 0.75 \%$ of the PPF increased the cement tensile strength by $18 \%$.

- From the thickening time test, it is observed that PPF acts as an accelerator as it speeds up the hydration reaction which suggests the ability to use the PPF as an alterna- 
tive material for silica floor in cementing shallow wells. Adding $0.75 \%$ BWOC of PPF to the base cement reduced the thickening time by $75 \%$.

- The addition of the PPF decreased the porosity and permeability of the cement matrix by filling the matrix pores and blocking the interconnection between the pores inside the cement matrix. The base cement porosity and permeability decreased by $16.8 \%$ and $56 \%$ by adding $0.75 \%$ of the PPF.

Open Access This article is distributed under the terms of the Creative Commons Attribution 4.0 International License (http://creativeco mmons.org/licenses/by/4.0/), which permits unrestricted use, distribution, and reproduction in any medium, provided you give appropriate credit to the original author(s) and the source, provide a link to the Creative Commons license, and indicate if changes were made.

\section{References}

Abid K, Gholami R, Choate P, Nagaratnam BH (2015) A review on cement degradation under $\mathrm{CO}_{2}$-rich environment of sequestration projects. J Nat Gas Sci Eng 27:1149-1157. https://doi. org/10.1016/j.jngse.2015.09.061

Al Maskary S, Halim AA, Al Menhali S (2014) Curing losses while drilling and cementing. In: Proceedings of the Abu Dhabi international petroleum exhibition and conference, Abu Dhabi, UAE, 10-13 Nov. SPE-171910-MS. https://doi.org/10.2118/171910-MS

Al-Buraik K, Al-Abdulqader K, Bsaibes R (1998) Prevention of shallow gas migration through cement. In: Proceedings of the IADC/ SPE Asia Pacific Drilling Technology, Jakarta, Indonesia, 7-9 Sept. SPE-47775-MS. https://doi.org/10.2118/47775-MS

API (2013) API recommended practice 10B-2: recommended practice for testing well cements, 2nd edn. American Petroleum Institute, Washington

API (2019) API specification 10A: cements and materials for well cementing, 25th edn. American Petroleum Institute, Washington

Arshad U, Jain B, Pardawalla H, Gupta N, Meyer A (2014) Engineered fiber-based loss circulation control pills to successfully combat severe loss circulation challenges during drilling and casing cementing in Northern Pakistan. In: Proceedings of the SPE Latin America and Caribbean petroleum engineering conference, Maracaibo, Venezuela, 21-23 May. SPE-169343-MS. https://doi. org/10.2118/169343-MS

ASTM (2016) ASTM C109/C109M. Standard test method for compressive strength of hydraulic cement mortars (Using 2-In. or [50$\mathrm{Mm}$ ] Cube Specimens). ASTM International, Pennsylvania, USA

Bahafid S, Ghabezloo S, Duc M, Faure P, Sulem J (2017) Effect of the hydration temperature on the microstructure of class $\mathrm{G}$ cement: C-S-H composition and density. Cem Concr Res 95:270-281. https://doi.org/10.1016/j.cemconres.2017.02.008

Bourgoyne AT, Millhelm KK, Chenevert ME, Young FS (1986) Applied drilling engineering. Society of Petroleum Engineers, Richardson. ISBN 1555630014

Brouwers H (2004) The work of Powers and Brownyard revisited: part 1. Cem Concr Res 34(9):1697-1716. https://doi.org/10.1016/j. cemconres.2004.05.031

Calvert DG, Smith DK (1990) API oilwell cementing practices. J Pet Technol 42(11):1364-1373. https://doi.org/10.2118/20816-PA
Duguid A, Radonjic M, Scherer GW (2011) Degradation of cement at the reservoir/cement interface from exposure to carbonated brine. Int J Greenh Gas Control 5:1413-1428. https://doi.org/10.1016/j. ijggc.2011.06.007

Elkatatny SM (2019) Development of a homogenous cement slurry using synthetic modified phyllosilicate while cementing HPHT wells. Sustainability 11(7):1923

Elmoneim HA, Zaki S, Al-Arda H (2000) Cementing the deepest 20-inch casing in Abu Dhabi using a combination of Noval Light Weight Slurry and Fiber. In: Proceedings of the Abu Dhabi international petroleum exhibition and conference, Abu Dhabi, UAE, 13-15 October. SPE-87283-MS. https://doi.org/10.2118/87283 -MS

Heinold T, Dillenbeck R, Rogers M (2002) The effect of key cement additives on the mechanical properties of normal density oil and gas well cement systems. In: Proceedings of the SPE Asia Pacific oil and gas conference and exhibition, Melbourne, Australia, 8-10 Oct. SPE-77867-MS. https://doi.org/10.2118/77867-MS

Ilyas M, Sadiq N, Mughal MA, Pardawalla H, Noor SM (2012) Improvement of cementing in deep wells. In: Proceedings of the SPE/PAPG annual technical conference, Islamabad, Pakistan, 3-5 Dec. SPE 163128-MS. https://doi.org/10.2118/163128-MS

Iremonger SS, Bolt M, Lawrence SC (2015) Enhanced thermal well integrity through the use of a new cement tensile strengthenhancing fiber. In: Proceedings of the SPE Canada heavy oil technical conference, Calgary, Alberta, Canada, 9-11 June. SPE174483-MS. https://doi.org/10.2118/174483-MS

Khattak MJ, Alrashidi M (2006) Durability and mechanistic characteristics of fiber reinforced soil-cement mixtures. Int J Pavement Eng 7(1):53-62. https://doi.org/10.1080/10298430500489207

Liu X, Wang R, Wu Z, Liu W (2012) The effect of triangle-shape carbon fiber on the flexural properties of the carbon fiber reinforced plastics. Mater Lett 73:21-23. https://doi.org/10.1016/j. matlet.2012.01.003

Luke K (2004) Phase studies of pozzolanic stabilized calcium silicate hydrates at 180 C. Cem Concr Res 34:1725-1732. https://doi. org/10.1016/j.cemconres.2004.05.021

Madhavi TC, Mallick A, Sohail MB, Nath S, Jain M (2015) Effect of copper slag on strength of polypropylene fiber reinforced concrete. Int J Eng Technol 7(4):1309-1322

Mahmoud AA, Elkatatny S (2019a) Effect of the temperature on the strength of nanoclay-based cement under geologic carbon sequestration. In: Proceedings of the 2019 AADE national technical conference and exhibition, Denver, Colorado, USA, 9-10 April. AADE-19-NTCE-066

Mahmoud AA, Elkatatny S (2019b) Mitigating $\mathrm{CO}_{2}$ reaction with hydrated oil well cement under geologic carbon sequestration using nanoclay particles. J Nat Gas Sci Eng 68:102902. https:// doi.org/10.1016/j.jngse.2019.102902

Mahmoud AA, Elkatatny S (2019c) Synthetic polypropylene fiber content influence on cement strength at high-temperature conditions. In: Proceedings of the 53rd US rock mechanics/geomechanics symposium held in New York, USA, 23-26 June. ARMA 19-1651

Mahmoud AA, Elkatatny S, Abdulmalek AS, Mahmoud M (2018) Nanoclay content influence on cement strength for oil wells subjected to cyclic steam injection and high-temperature conditions. In: Proceedings of the Abu Dhabi international petroleum exhibition and conference, Abu Dhabi, UAE, 12-15 Nov. SPE-193059-MS. https ://doi.org/10.2118/193059-MS

Mahmoud AA, Elkatatny S, Abdulmalek AS, Gajbhiye R (2019) Influence of nanoclay content on cement matrix for oil wells subjected to cyclic steam injection. Materials 12(9):1452. https://doi. org/10.3390/ma12091452

Messier E, Stiles D, Morgan R (2003) Controlling cement tops through use of fibre-based slurries reduces drilling costs. Journal 
of Canadian Petroleum Technology 42(5):15-19. https://doi. org/10.2118/03-05-TN

Morris W, Criado MA, Robles J, Bianchi G (2003) Design of high toughness cement for effective long lasting well isolations. In: Proceedings of the SPE Latin American and Caribbean petroleum engineering conference, Port-of-Spain, Trinidad and Tobago, 27-30 April. SPE-81001-MS. https://doi.org/10.2118/81001-MS

Musenda C (1999) Effects of fiber reinforcement on strength and volume change behavior of expansive soils. Master thesis, The University of Texas at Arlington, Arlington, Texas

Nelson EB, Guillot D (2006) Well cementing, 2nd edn. Sugar Land, Schlumberger. ISBN 0978853008

Parcevaux PA, Sault PH (1984) Cement shrinkage and elasticity: a new approach for a good zonal isolation. In: Proceedings of the SPE annual technical conference and exhibition, Houston, Texas, 16-19 Sept. SPE-13176-MS. https://doi.org/10.2118/13176-MS

Park S-J, Seo M-K, Shim H-B (2003) Effect of fiber shapes on physical characteristics of non-circular carbon fibers-reinforced composites. Mater Sci Eng A 352(1-2):34-39. https://doi.org/10.1016/ S0921-5093(02)00463-X

Patel H, Patel C, Patel K, Balya MI, Patel VA (2015) Performance evaluation of polymer fiber 'RECRON-3S' in pavement quality concrete. Int J Sci Res Dev 2(11):457-461

Puppala J, Musenda C (2000) Effects of fiber reinforcement on strength and volume change behavior of expansive soils. Transp Res Rec 1736:134-140. https://doi.org/10.3141/1736-17

Rogers MJ, Dillenbeck RL, Eid RN (2004) Transition time of cement slurries, definitions and misconceptions, related to annular fluid migration. In: Proceedings of the SPE annual technical conference and exhibition, Houston, Texas, 26-29 Sept. SPE-90829-MS. https://doi.org/10.2118/90829-MS

Santoni L, Tingle S, Webster L (2001) Engineering properties of sandfiber mixtures for road construction. J Geotech Geoenviron Eng 127(3):258-268

Shahriar A (2011) Investigation on rheology of oil well cement slurries. Ph.D. dissertation, University of Western Ontario. https:// ir.lib.uwo.ca/cgi/viewcontent.cgi? article $=1231 \&$ context $=$ etd. Accessed 8 Nov 2018
Shi G, Liu W, Gao Y (1995) Modifying set cement performance for improving cementing job quality. In: Proceedings of the international meeting on petroleum engineering, Beijing, China, 14-17 Nov. SPE-29924-MS. https://doi.org/10.2118/29924-MS

Tang C, Shi B, Gao W, Chen F, Cai Y (2007) Strength and mechanical behavior of short polypropylene fiber reinforced and cement stabilized clayey soil. Geotext Geomembr 25(3):194-202. https ://doi.org/10.1016/j.geotexmem.2006.11.002

Taylor HFW (1997) Cement chemistry, 2nd edn. Thomas Telford Publishing, London. ISBN 0727725920

Ugwu IO (2008) Cement fatigue and HPHT well integrity with application to life of well prediction. Master thesis, Texas A\&M University. https://oaktrust.library.tamu.edu/bitstream/handle/1969.1/ ETD-TAMU-2351/UGWU-THESIS.pdf?sequence=1\&isAll owed $=\mathrm{y}$. Accessed 1 Nov 2018

Vasudev D (2007) Performance studies on rigid pavement sections built on stabilized sulfate soils. Master Thesis, University of Texas at Arlington. https://rc.library.uta.edu/uta-ir/bitstream/handle/10106 /423/umi-uta-1647.pdf? sequence=1\&isAllowed=y. Accessed 15 Oct 2018

Viswanadham S, Phanikumar R, Mukherjee V (2009) Swelling behavior of a geofiberreinforced expansive soil. Geotext Geomembr 27(1):73-76. https://doi.org/10.1016/j.geotexmem.2008.06.002

Yetimoglu T, Salbas O (2003) A study on shear strength of sands reinforced with randomly distributed discrete fibers. Geotext Geomembr 21(2):103-110. https://doi.org/10.1016/S0266 -1144(03)00003-7

Yetimoglu T, Inanir M, Inanir OE (2005) A study on bearing capacity of randomly distributed fiber-reinforced sand fills overlying soft clay. Geotext Geomembr 23(2):174-183. https://doi. org/10.1016/j.geotexmem.2004.09.004

Publisher's Note Springer Nature remains neutral with regard to jurisdictional claims in published maps and institutional affiliations. 